IRSTI 17.07.61

\author{
Nurmukhanbetova A.A. ${ }^{1}$, Tsyganova V.A. ${ }^{2}$, Issabayeva B. ${ }^{3}$, \\ ${ }^{1}$ senior lecturer, ${ }^{2}$ Master of Arts, teacher, ${ }^{3}$ Master of Arts, senior lecturer \\ of Al-Farabi Kazakh National University, Kazakhstan, Almaty, \\ e-mail: bayanaisabaeva@gmail.com
}

\title{
LINGUO-CULTURAL ASPECT \\ IN LEARNING FOREIGN LANGUAGES
}

Culture has taken a special place in language teaching and language learning. It has been recognized that culture and language are closely interrelated and language could be used as an important medium through which culture is expressed.

One of the ways of stimulating students' curiosity toward the target culture and their own is exploring culture-based activities by using authentic materials and our own experience as EFL teachers (English as a Foreign Language).

These activities contribute to enriching the students' knowledge of the target culture and lead them to a more critical understanding of both their own and other communities.

Key words: advantage, effect, enrich, experience, critical thinking, curiosity, interact, linguo-cultural aspect.

\author{
Нұрмуханбетова Ә.Ә. ${ }^{1}$, Цыганова В.А. ${ }^{2}$, Исабаева Б. ${ }^{3}$, \\ әл-Фараби атындағы Қазақ ұлттық, университетінің \\ 1аға оқытушысы, ${ }^{2}$ магистрі, оқытушысы, ${ }^{3}$ магистр, аға оқытушысы, \\ Қазақстан, Алматы қ., е-mail: bayanaisabaeva@gmail.com
}

Шетел тілін үйретудің мингво-мәдени тәсілі

Қазіргі кезде тіл сөздік қор ғана емес, сонымен қатар өз ой-пікірін жеткізу, барлық ілім-білім Аеңгейін көрсету және дүниетанымы туралы түсінігін білдірудің құралы болып табылады.

Біз ойлау қабілетіміз арқылы белгілі бір мәдени деңгейде дүниені танып білеміз және айналадан алған әсерімізді, пікірімізді, эмоциямызды тіл арқылы жеткіземіз.

Тіл мен мәдениет түсінігі түйісетін арнада пайда болған лингво-мәдени тәсілі тілАік және мәдениаралық қарым-қатынастың аспектілерін қамтиды.

Сондықтан тілді осы тұрғыда қарастыру студенттерге кез келген елАің ұлттық, ерекшіліктеріне, географиясы мен тарихына, салт-дәстүрлеріне, мәдениеті мен шығармашылығына сүйене отырып үйренуге мүмкінАік береді.

Түйін сөздер: артықшылық, тиімділік, байыту, тәжірибе, сыни ойлау, өзара әрекет, мингвомәдени тәсі^, сыни пікір.

Нурмуханбетова А.А. ${ }^{1}$, Цыганова В.А. ${ }^{2}$, Исабаева Б. ${ }^{3}$, ${ }^{1}$ старший преподаватель, ${ }^{2}$ магистр, преподаватель, ${ }^{3}$ магистр, старший преподаватель Казахского национального университета им. аль-Фараби,

Казахстан, г. Алматы, e-mail: bayanaisabaeva@gmail.com

\section{Аингво-культурный аспект при изучении иностранных языков}

Сегодня язык - это не только словарный запас, но и способ самовыражения, способный выразить всю совокупность знаний и преАставлений человека о мире.

Мы познаём мир посредством мыщления в определённом культурном поле и пользуемся языком Аля выражения своих впечатлений, мнений, эмоций и восприятий. 
Аингво-культурный метод, возникший на стыке понятий язык и культура, предполагает Ава аспекта общения - языковое и межкультурное.

Поэтому такой подход к изучению языка поможет студенту мегко ориентироваться в национальных особенностях, географии, истории, обычаях и традициях, культуре и творчестве той или иной страны.

Ключевые слова: преимущество, эффект, обогащать, опыт, критическое мышление, ^юбознательность, взаимодействовать, мингво-культурный метод.

\section{Introduction}

Modern world is represented by a great variety of cultures, each of them being associated with a particular language. Therefore, the knowledge of a language is part of a particular culture. The present article deals with the problem of their interrelation based on the materials of the English language and culture. The purpose of the article is an attempt to distinguish those aspects of the problem that are essential for language teaching.

Nowadays with the invention of electronic media, oral speech has become a means of international communication of both oral and written speech.

The language suggests that it influences not only culture, but its functional properties as well. (Nascimenko G. P., 2000: 39).

Language and culture are in a relationship of interdependence and mutual influence, that is, a language cannot exist outside of culture, the latter cannot exist without a language. Language is considered to be as a product of culture (inherited from our ancestors), as well as a condition of culture, through which we assimilate it. (Sabitova Z. K., 2011:20).

Being foreign language teachers we should take advantage of our position to widen the possibilities of developing students'intercultural awareness.

While studying materials in our text-books students gain a lot of information about the life in English-speaking countries. And here we would like to suggest the idea that along with speaking of wonderful places of interest of London or Washington or learning some facts on geography or government structure of a foreign country we should remember to make them speak on the same notions of our own country. This will encourage them to use the language skills they've just acquired to describe their own motherland in real practice.

After studying the text about the UK students speak of Kazakhstan's geography, its state structure, state emblem, industry, etc. Actually we use the map of Great Britain as well as that of Kazakhstan, pictures of state symbols of both countries and discuss cultural tradition of both nations.
The text about Tate gallery touches upon the subject of fine arts and the artist's life. The students were asked if they knew anything about the painters mentioned in the text (Rembrandt, Manet, Monet, Degas). They were also given supplementary texts about Michelangelo, Van Gogh and Picasso.

The students made reports on a contemporary Kazakh painter Abilkhan Kasteev, his life and views on modern art. They could widen the scope of their cultural awareness.

A special field of interest for English teachers is poetry, since learning poems gets students to appreciate all the beauty expressed by matching sounds and rhythm in a piece of poetry.

The students were given a number of poems by English and American poets. Reciting them by heart was followed by translating some of them into their mother tongue. Mention should be noted that through our students are future geographers, not specialists in literature, they succeeded in fulfilling this rather challenging task. So, in our opinion, learning poems in a foreign language and translating them into their native language is the most effective way to develop students' intercultural awareness as well as to make them well-bred people.

As A. Humboldt states, poetry can be expressed by means of a language. This short characteristics implies the nature of poetry. Arttends to be the world's mirror that surrounds man. That is why poetry is intended for things of dowel naturethat is man and the world (Humboldt W., 1983:193).

Scientists suggest that the first step in being a good intercultural communicator is to know your own culture. Foreigners like asking questions concerning any field of life: science, society, family relations, agriculture, etc. of the country you live in.

So, learning a foreign language and using authentic material to be rendered are instruments for developing students' intercultural awareness.

The more we know about different cultures of our neighbours, the better we can recognize and understand people around. Developing intercultural awareness will certainly make them intelligent people who could be tolerant to any beliefs and behaviours. 
They will become people who are worth to represent their country at any level.

At the present stage of development of society with the expansion of economic ties and contacts marked globalization of the world, involving the rapprochement of people, strengthening their intercultural interaction. However, each society has a special national culture, which is reflected in the language. Features of culture affect the formation of the inner world of man, determine his national mentality. It is important to take into account the specifics of the national worldview not only in translation activities when extracting cultural information from language units, but also in the process of teaching foreign languages, to form a holistic understanding of the language and culture in students. This provision is the basis of the idea of implementation of linguocultural approach in teaching a foreign language.Modern society needs specialists, who can adequately represent themselves and their culture in the international arena, which can be carried out only on the principles of integration and dialogue of cultures. Foreign language training of students should not be limited to the development of speech skills in the target language, but also we should take into account the relationship and interaction of culture and language in its functioning. This is the idea of implementing a linguocultural approach in teaching foreign languages to students.

The General trend of humanization of education over the past decade has raised the issue of considering education in the context of culture.In the field of theory of teaching a foreign language, this trend is manifested in the recognition of the fact, that the mastery of a foreign language is, first of all, the introduction to a different culture and new sociocultural content.

One of the most important components of any culture is professional human's activity, which plays a crucial role in the process of its formation. This professional activity contains significant information about the culture of the studied language and it gives an idea of the history of professional activity of the country and the latest changes in society.

The increasing role of foreign languages in the life of modern society, the need for specialists, who are able to effectively carry out the process of intercultural communication increases, which involves the formation of not only language, but also cognitive consciousness of students. Students need to learn a wide range of background knowledge about the countries of the target language.

However, the methodology of teaching a foreign language as an aspect of foreign language culture in non-linguistic universities has not been developed enough. The awareness of the need to include a foreign language culture in the process of teaching a foreign language in most cases is expressed either in the introduction of disparate fragments of information about the country in the classroom for the practice of language or in the development of courses of lectures on the history and culture of the country. This problem is especially evident in the work with the texts of mass communication. The constant enrichment of language due to reflection in it of changes of life of society, compactness of information counting on its general knowledge in this society demand from the student not only the created secondary language, but also cognitive consciousness. At the moment, there are not enough developed techniques that involve the introduction of the student to a foreign-language picture of the world.The analysis of the formation of students of non-linguistic faculties of the skills of semantic perception of texts of modern foreign-language media showed, that most students experience difficulties of linguistic and cultural nature.

The researchers emphasize the importance of teaching a foreign language as a component of culture and recognize the fact, that a new stage of development of this problem has come, that meets both the increased needs of educational process and a profound understanding of questions concerning the relationship between language and culture and its reflection in a language teaching practice. Most of the work on this issue was done within the framework of a linguo-cultural approach to language teaching.It focuses mainly on the development of lexical skills based on linguistic and cultural materials, that is consideredto be a prerequisite of intercultural communication according to I.I. Khaleeva. The application of linguo-cultural approach to teaching foreign languages makes it possible to solve the problem of cognitive consciousness formation.

Learning foreign languages is of great importance now as it allows to enter into contact with other realities to understand mentality and customs. In fact, the English language is an important lingua france, i. e. a language spread among native speakers of various languages as well as was Latin during the medieval period.

According to anthropologists, culture is «the whole way of life of people or group. In this context culture includes all the social practices that bond a group of people together and distinguish them from others.» (Winfield F., Barnes-Felfebi., 1982:23). So the classroom context is a good example of a 
cultural group and being so, it can be regarded as an excellent phenomenon to be observed.

Some researchers have investigated classroom settings under two viewpoints: social interaction and language learning that led them to realize that culture is not only present in the classroom set but also in the language that is being taught.According to L.V. Scherba, «Language and thinking are an inseparable thing, which cannot be detached by a person who speaks his mother tongue» (Filippova M.M., 2008:110).

Modern world is integrating due to the opening of worldwide trade and media markets but showing signs of culturalism and nationalism as well. With English generally being seen as the main lingua franca for international contact, English teachers can expect to see the signs of a «global village» in their classes with students expecting to use English as a tool for their own specific purposes which may not include use in a native-speaking country.

That is why we can support the use of student's native culture as a cultural content in the English language classroom.

A wide range of studies has shown that using a content that is familiar to students can influence students' comprehension of a second language.

An additional advantage to students for using a content from their own cultures in learning the English language can be their ability in selfexpression when they have to explore their changing identities in a new linguistic environment. Students feel that they have «no words» to express culture-based themes such as family values. So English could be used as a tool to express such themes.

Using a native culture in class can enhance student motivation and make it possible for greater sensitivity to students' aims in learning the language.

Today some researchers believe that cultural learning affects students' linguistic success in foreign language learning in a positive way. Others suppose that culture can be used as an instrument in the process of communication (Post R., Rathet I., 1996: 5). In our opinion, culture must not be seen as a support to language teaching but it should be placed on an equal level with a foreign language teaching.

Culture has taken an important place in language teaching and language studies. It has been recognized that culture and language are interrelated and language can be used as the main medium through which culture is expressed. We think, in foreign language classrooms "pure information» is useful but it does not necessarily leads us to insight whereas the development of people's cultural awarenessleads us to critical thinking (Kabden N., Parkhatova R., 2002: 14).

But in what way can we «teach» culture to the Kazakh and Russian foreign language students who do not have close contacts with native speakers of English and have little opportunity to discover how these speakers feel, think and interact with others in their own peer group? How can we stimulate their curiosity about the target of culture when they do not have enough time to learn the formal properties of the language? Perhaps one of ways of doing so is by exploring culture-based activities.

The idea of developing a set of activities lies in the fact that despite the fact that teaching EFL (English as a foreign language) has become widespread in all the levels of Kazakhstan education, teachers still lack resource material for exploring the target culture in the classroom.

Actually, there are some books in the area, but they are not concerned with similarities and differences between Kazakh and Russian culture and those of English-speaking countries.

The activities described in the present article are suitable for primary, secondary and higher educational teachers as well as private school professionals who wish to develop a programme where language and culture are interrelated and have the same level of importance.

The aim of these activities is increasing students' awareness and developing their curiosity towards the target culture and their own, helping them to make comparisons among countries.

These comparisons can enrich students' experience and make them aware that although some culture elements are being globalized, there is still diversity among cultures. This diversity should be understood and respected and never over or underestimated (Straut H., 2005: 5).

We do not mean to emphasize only one target culture such as the British or the American. Instead, we choose a miscellaneous style in which cultural elements of any English speaking country could be employed in an activity.

On the other hand, this variety of cultures was grouped under predetermined cultural topics. What do we mean by cultural topics? When discussing them, we consider all the properties included in the definition of the word culture (e.g. cultural artifacts, family talk). These properties are practically impossible to be explored by all activities (Turasheva M.B., 2003: 32).

The following topics are presented with no concern for order of importance:

- Social identity: groups characterized by social class, ethnic minorities; 
- Social interaction at different levels of familiarity;

- Belief and behavior: patterns of everyday life;

- Socio-practical institutions: institutions of the state and socialization such as ceremonies;

- National history and geography: historical events, geographical places;

Media: TV, newspaper, radio;

Art : literature, cinema, theatre.

\section{Experiment}

We developed classroom activities for these categories by using authentic materials and our own personal experience as EFL teachers.

These activities can be described under the following headings:

- Aims

- Materials

- Level

- Preparation

- Procedure

- Follow-up

- Variation

They are devised in such a way that allows the teacher the flexibility to adapt them according to his/ her needs and audience. Whenever possible we also inserted some linguistic items which can be used together with the cultural aspect emphasized. This is due to the fact that in Kazakhstan education systems cultural studies are not observed as a separate subject.(Kabden N., Parkhatova R., 2002: 16).

English-speaking countries

Aims: - Indicating the geographical location of some English-speaking countries;

- Raising the learners' awareness of the geographical extent of the English language usage;

- Introducing vocabulary related to countries and respective languages.

Materials: photocopies of the world map;cardscontaining names of countries.

Level: Elementary/Pre-intermediate.

Preparation:

- Photocopy of the world map (1 copy per student);

- Preparing about 20-25 cards and writing the name of a different country in each one.

In group: 1) Indicating the countries in the cards;

Marking the English-speaking countries (with different colour pencil).

Procedure:

- Presenting the cards to the class;

- Dividing the class into pairs or small groups and handing out the copies of the world map;
- Asking the students to locate on the world map the countries listed on the cards.

- During this stage make sure that groups are carrying on a discussion and filling in the map properly;

Telling them to highlight the English-speaking countries.

Checking the answers with the whole class.

Ending the activity with a brief discussion on the geographical extent of the usage of the English language in the world.

Follow-up:

The present activity may be followed by the exposition and practice of the following items:

Where is/are he/she/they from? with the presentation of photos of famous people from English-speaking countries.

Variation:

The cards with the names of the countries can be made by students in case they have acquired the specific vocabulary to do so.

The number of countries or cards should be increased or reduced depending on the students' level. It is important to include English-speaking countries the students have little or no knowledge of.

Matching and comparing socio-political institutions.

Aims:

- Comparing socio-political institutions (including their representatives and symbols) from Kazakhstan, the USA and the UK;

- Raising learners' awareness of the similarities and differences betweensocio-political institutions from the countries mentioned above;

- Introducing vocabulary related to the topic;

- Practicing the grammar items in questions and answers.

Materials:

- Cards containing names of institutions.

Levels:

Elementary/Pre-intermediate.

Preparations:

- Preparing cards and writing the name of a socio-political item (institution, representative or symbol) in each one. The following items can be divided into 10 categories:

- Country: The republic of Kazakhstan / The USA, The UK;

- Head of state/government: President N. Nazarbayev / President D. Trump / Queen Elizabeth II and / or Prime Minister T. May.

Type of government: Constitutional Republic/ Federal Republic/Constitutional Monarchy; 
Representatives: Parliament / Congress / Parliament;

Official residence: Parliament House / The White House / Buckingham palace and 10 Downing St.;

Official document: Constitution / US. Constitution / Magna Carta;

Famous politician: D. Kunaev / A. Lincoln / W. Churchill;

Flag: Kazakhstan flag/Stars and stripes / Union Jack;

National anthem: Anthem of Kazakhstan / Starsprangled Banner / God save the Queen;

Currency: Tenge / Dollar / Pound.

Procedure:

Handing out one card to every student and asking the class to divide into groups of three according to the categories they have got in common. E.g., the student receiving the card that contains Tenge books for the classmates who receive the cards containing Dollar and Pound.

Checking whether learners have formed the groups in a proper way by asking each group to show their cards to the class and indicate the category they belong to. While doing it, list the 10 categories shown on the board.

Asking students to rearrange themselves into 3 groups according to nationality. E.g., the student who gets the card containing Tenge must group together with those who have cards with the other items related to Kazakhstan.

Writing the names of the three nationalities which were explored on the board and finish this activity by reviewing all the categories.

Speaking about the peculiarities of national thinking style, we turn to the fact that many units in the English system of measures and weights are specific for this culture, e.g. an inch, a pound, a mile, an ounce. Due to the fact that these words have been used for centuries, there are a number of such phraseological units as «every inch of it »- до мозга костей; «give smb. an inch and he will take a mile» - дай ему палец, он и руку отхватит; «an inch breaks no square» (proverb) - не всякое лыко в строку; «a pound to a penny» - держу пари; «take care of the pence and the pounds will take care of themselves» - копейка рубль бережет, etc.

Mention should be made that both phraseological units and their equivalents in different languages can illustrate the specificity of national thinking. (Filippova M.M.,2008:124).

\section{Results and discussion}

So, the first step in being a good inter - cultural communicator is to know your own culture and yourself. Foreigners like asking a lot of questions concerning any field of life such as science, society, family relations, agriculture, politics, etc. of the country you live in.

The majority of scientists including M.I. Issayev consider a language as a means of communication and interaction.(Issayev M.I., 1992: 5). So, learning a foreign language and using authentic material to be rendered as well as translation practice are good instruments for developing students (inter) - cultural awareness.

The more we know about the different cultures of our global neighbours, the better prepared we are to recognize and understand people around. Developing (inter) - cultural awareness will make them highly cultured, intelligent people who are tolerant to any beliefs and behaviours. They will be people worthy to represent their own country and nation at any level.

The dialogue of cultures provides mutual understanding and helps to understand your own culture better. D.S. Likhachev points out that the real values of culture can be developed only in contact with other cultures taking into account our neighbors' experience.» (Sabitova Z.K., 2011: 21).

\section{Conclusion}

Mention should be noted that all these activities have been used in our university classroom context and the results were quite successful.

The activities enriched the students' knowledge of the target culture and led them to a more critical understanding of both their own and other communities.

Linguo-cultural approach is one of the most effective. This approach forms and improves the skills and habits of intercultural communication through the study of a foreign language as a cultural phenomenon. So, in this approach, along with the language, culture is the main content of education. It is the linguocultural approach that makes it possible to avoid a simplified, factual, fragmentary approach to familiarizing students with certain aspects of culture. Furthermore, it allows students to form a fairly complete picture of a foreign language reality through the study of both linguistic and non-linguistic content of cultural areas.

Thus, we can arrive at conclusion that the relationship between culture and language is cognitive and pragmatic. Being a means of culture transmission, a language can be considered as an essential part of culture. 


\section{Литература}

Нещименко Г.П. К постановке проблемы «Язык как средство трансляции культуры» // Язык как средство трансляции культуры. - М.: Наука, 2000. - С.39.

Сабитова 3.К. Лингвокультурологические аспекты изучения взаимоотношения языка и культуры // Вестник КазНУ. Серия филологическая. - 2011. - № 2(132). - С. 20-21.

Гумбольд В. Язык и философия культуры. - М.: Педагогика, 1983. - 349 с.

Winfield F., Barnes-Felfebi. The effects of familiar and unfamiliar cultural context on foreign language composition // Modern language journal. - 1982. - C.373.

Филипова М.М. Взаимосвязь языка, мышления и культуры и преподавания иностранного языка / Язык, сознание, коммуникация: Сб.статей / Отв. ред. В.В. Красных, А.И. Изотов - М.: МАКС пресс, 2008. - Вып. 36. - С. 110 -124.

Post R., Rathet I. On their own terms. - Oxford University Press. 1996. - C. 5.

Кабден Н., Пархатова Р. Язык и культура // Материалы Республиканской научно-практической конференции. - Алматы, 2002. - Вып. 1.- С. 14-16.

Straut H. Designing a cross-cultural course. // Forum. 2005. - C.5.

Турашева М. В. Why we should develop cultural awareness. // Новые технологии в обучения зыкам. - 2003. - Вып. 2. C. 119.

Исаев М.И. Взаимосвязь и взаимообусловленность языка и культуры // Русский язык в СНГ. - 1992. - №1. - С.5.

\section{References}

Filippova M. M. (2008). Vzaimosvyaz yazyka, myshleniya i kultury i prepodavaniya inostrannogo yazyka [Relationship of language, thought and culture and foreign language teaching]. Language, consciousness, communication: collection of articles / Executive editor V. V. Krasnykh,A. I. Izotov. M.:MAX press. Issue.36. Pp.110-124 (In Russian)

Humboldt W. (1983). Yazyk i filosofiya kultury [Language and philosophy of culture]. M.: Pedagogy. 349 p. (In Russian)

Issayev M. I. (1992). Vzaimosvyaz i vzaimoobuslovlennost yazyka i kultury [Interrelation and interdependence of language and culture]. Russian language in the CIS. No. 1. P. 5. (In Russian)

Kabden N., Parkhatova R. (2002). Yazyk i kultura [Language and culture]. Materials of the Republic scientific and pracrical conference . Issue 1. Pp. 14-16 (In English)

Nascimenko G.P. ( 2000). K postanovke problemy yazyk kak sredstvo translyatsii kultury [To the problem statement «Language as a means of cultural transmission»]. Language as a means of cultural transmission. Moscow: Science. P. 39 (In Russian)

Post R., Rathet I. (1996). On their own terms. - Oxford University Press. P.5 (In English)

Sabitova Z. K. (2011). Lingvokulturologicheskiye aspekty izucheniya vzaimootnosheniya yazyka i kultury [Linguoculturological aspects of studying the relationship between language and culture]. KazNU Bulletin Philology series. No. 2 (132). Pp. 20-21 (In Russian)

Straut H. (2005). Designing a cross-cultural course. Forum. P. 5. (In English)

Turasheva M.B. (2003). Why we should develop cultural awareness. // New technologies in language learning. Issue 2. P. 119. (In English)

Winfield F., Barnes-Felfebi. (1982). The effects of familiar and unfamiliar cultural context on foreign language composition. Modern language journal. P. 373. (In English) 